$7^{\circ}$ Simposio Internacional de Investigación Multidisciplinaria / Ciencias de la Salud 7th Internationalm Symposium on Multidisciplinary Research / Health Sciences

\title{
CS-18 Diseño de una formulación a partir de extractos de kalahuala (Phlebodium pseudoaureum) para un posible uso como agente antisolar
}

\author{
Design of a formulation from extracts of kalahuala (Phlebodium pseudoaureum) \\ for a possible use as a solar control agent \\ Sully M. Cruz, Maria C. Menéndez, Ana C. Valdez, Aylin Santizo, Armando Cáceres
}

Facultad de Ciencias Químicas y Farmacia, Universidad de San Carlos de Guatemala, Guatemala

*Autor al que se dirige la correspondencia: smargotcv@gmail.com

\section{Resumen}

$\mathrm{L}$ a kalahuala (Polypodium leucotomos y Phlebodium pseudoaureum) es un especie medicinal que tiene potencial en cosmética por sus propiedades fotoprotectoras, antioxidantes y antipsoriasis. En este estudio se diseñó una formulación cosmética a partir de extractos de $P$. pseudoaureum, se establecieron los parámetros de calidad para su uso como agente antisolar, se caracterizó la droga vegetal y extractos por pruebas fisicoquímicas, fitoquímicas y microbiológicas para evaluar su identidad y pureza. Se determinó y evaluó el espectro de absorción de los extractos de P. pseudoaureum para determinar el factor de protección solar y se midieron los flavonoides totales por espectrofotometría. Por pruebas fitoquímicas se detectó la presencia de flavonoides, saponinas y taninos en los extractos de fronda y en los de rizoma se evidenciaron además cumarinas. Los dos extractos absorbieron radiación ultravioleta en longitudes de onda que corresponden a la región UVC y asociados con el octilmetoxicinamato absorbieron energía en longitudes de onda cercanas a la región de máximo efecto eritematoso, presentando un efecto sinérgico en su capacidad de absorción de energía en el rango UVB. Los extractos de fronda presentaron $>0.5 \%$ de flavonoides, así como el mayor factor de protección solar hasta 10, por lo que fueron los de elección para la formulación fitocosmética, cumpliendo con los parámetros de calidad organoléptica, fisicoquímica y microbiológica, demostraron efectividad en la crema y gel formulado manteniendo sus características a lo largo del tiempo según el estudio de estabilidad.

Palabras claves: frondas, flavonoides, factor de protección solar, crema, gel

Abstract

$\mathrm{K}$ alahuala (Polypodium leucotomos and Phlebodium pseudoaureum) is a medicinal species with potential in cosmetics for its photoprotective, antioxidants and antipsoriasis properties. In this study a cosmetic formulation from extracts of P. pseudoaureum was designed, establishing quality parameters for its use as a sunscreen, the drug was characterized by testing plant extracts and physicochemical, phytochemical and microbiological to asess its identity and purity. it was determined and evaluated the absorption spectrum of P. pseudoaureum extracts to determine the sun protection factor and total flavonoids were identified by spectrophotometry. By phytochemical tests the presence of flavonoids, saponins, coumarins and tannins were detected in frond and rhizome extracts. Both extracts absorbed ultraviolet radiation at wavelengths that correspond to the region associated with UVC and octyl methoxycinnamate absorbed energy wavelengths near the region of maximum erythematosus effect, showing a synergistic effect on energy absorptive capacity in the UVB range. The extracts showed flavonoids in percentages $>0.5 \%$, the highest sun protection factor of 10 , so were selected formulationsfor phytocosmetics, fulfilling the quality parameters of organoleptic, physicochemical and microbiological efficacy in the cream and gel formulated to maintain their characteristics over time according to the stability study. 